Bieri, D. S. (2021): "Central Banks and the Governance of Monetary Space” in Knox-Hayes, J. and D. Wójcik (eds) The Routledge Handbook of Financial Geography, pp. 483-509. Routledge Companions, New York and London: Routledge.

\title{
22 \\ CENTRAL BANKS AND THE GOVERNANCE OF MONETARY SPACE
}

\author{
David S. Bieri
}

\section{Introduction}

From regional redistribution through mortgage markets to the monetary policy effects on local house price dynamics, the Great Financial Crisis (GFC) has been a powerful reminder that money and credit-always and everywherematter for the evolution of the space-economy. In addition to the spatially uneven impact of money and credit, the GFC has also demonstrated that the role of central banks is second-to-none in constituting the pivot points on which the global financial system hinges. It was the extreme measures by central banks - on their own, and in transnational coordination - that prevented the complete collapse of financial markets around the globe as interbank-funding came to a grinding halt and money markets began to seize up in the late 2000s.

With the financial system no longer capable of performing its core intermediation functions - liquidity, maturity, and credit transformation — central banks were forced to set in motion all the conventional levers of policy intervention, and, in the process, even invented new ones. While the unprecedented amounts of short-term liquidity injected into the system had averted the worst in the immediate aftermath of the Lehman Brothers collapse, policy rates were now near, or at, the zero lower bound. The conventional monetary policy approaches of the post-war period had become impotent, caught up in what Keynes had foreseen as a 'liquidity trap' wherein normal policy action was akin to 'pushing on a string'. Central banks, led by the Federal Reserve and its global monetary allies - the European Central Bank (ECB), the Bank of England (BoE), the Bank of Japan (BoJ), and the Swiss National Bank (SNB), collectively known as the C5-began to push the envelopes of their policy remits, testing new approaches and new instruments, ranging from special lending programs to the brute-force large-scale asset purchases that became known as 'quantitative easing' (QE). 
These unconventional policy actions soon made clear that the GFC had precipitated central banking into a new evolutionary stage. A decade on, this 'new age of central banking' now appears firmly entrenched and largely normalized. ${ }^{1}$ In addition to their time-tested role as lenders of last resort (LOLR), post-crisis central banks also began to act as 'dealers of last resort' (Mehrling, 2011) and, in doing so, they have been collapsing much of the post-crisis activity in financial markets onto their own balance sheets. Such crowding out of large swathes of trading volumes between private financial intermediaries meant that central banks effectively become the 'only game in town' (El-Erian, 2016).

Indeed, the strategic use of central banks' balance sheet via these 'nontraditional actions' has given rise to some of the most striking facts of the post-crisis normal. For example, the combined assets of the 10 central banks with the largest growth in their foreign exchange reserves and balance sheets over the post-crisis decade currently amount to over US $\$ 17$ trillion (Table 22.1). This is roughly the same as the total assets of the world's 10 largest, privately owned financial conglomerates. ${ }^{2}$ By comparison - and in some ways a measure of the extreme financialization of the global economy-the combined assets of the world's 75 largest non-financial institutions is less than US $\$ 15$ trillion. ${ }^{3}$ Table 22.1 also reveals that the largest balance sheet growth was recorded by those central banks with the most active QE programs; that is, the Fed, BoE, BoJ, and ECB (and some of its member central banks) - a direct consequence of the balance sheet mechanics of their large-scale asset purchases. In fact, the combined assets of the C5 central banks currently account for almost $40 \%$ of the GDP of the advanced economies they represent.

Since economics is, as Michał Kalecki is famously said to have quipped, "the science of confusing stocks with flows", it behooves us to quantify briefly the pure flow dimension of these extraordinary actions by central banks. Between 2007 and 2019, the cumulative QE related transaction volumes of these central banks reached a staggering US $\$ 197$ trillion—an amount so vast that it would have been enough to acquire the total output of the world's largest economy in each year over that same period; that is, the combined flow of all goods and services produced in the United States since the GFC (see Figure 22.1).

However, unconventional policy actions and bloated balance sheets were not limited to the central banks of the core economies. Indeed, the policy activism of QE has led to broad-based policy concerns over a 'monetization of debt' and over the distributional effects of negative interest rate policies around the globe.And, as part of these concerns, the role of central bank independence (CBI) - one of the most sacred institutional policy arrangements of the postwar period-has come under close scrutiny again as board discontent with the growing inequalities of the post-crisis environment has fanned the flames of populism worldwide. ${ }^{4}$

But there were also fewer visible signs that, once they had saved the (financial) world, central bankers engineered a more subtle transformation of the international monetary system (IMS). First and foremost, perhaps, is an unprecedented 


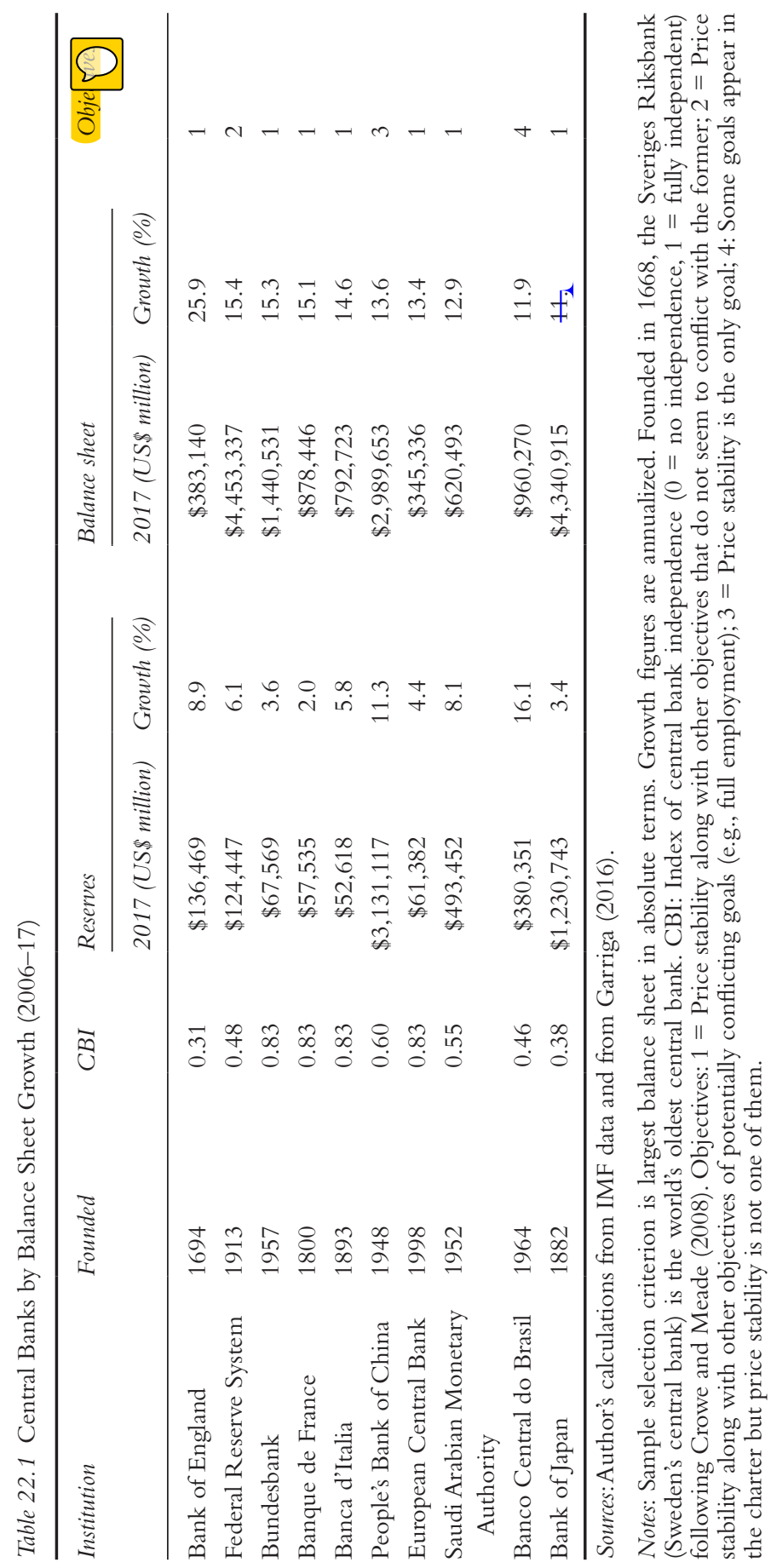

(6) 


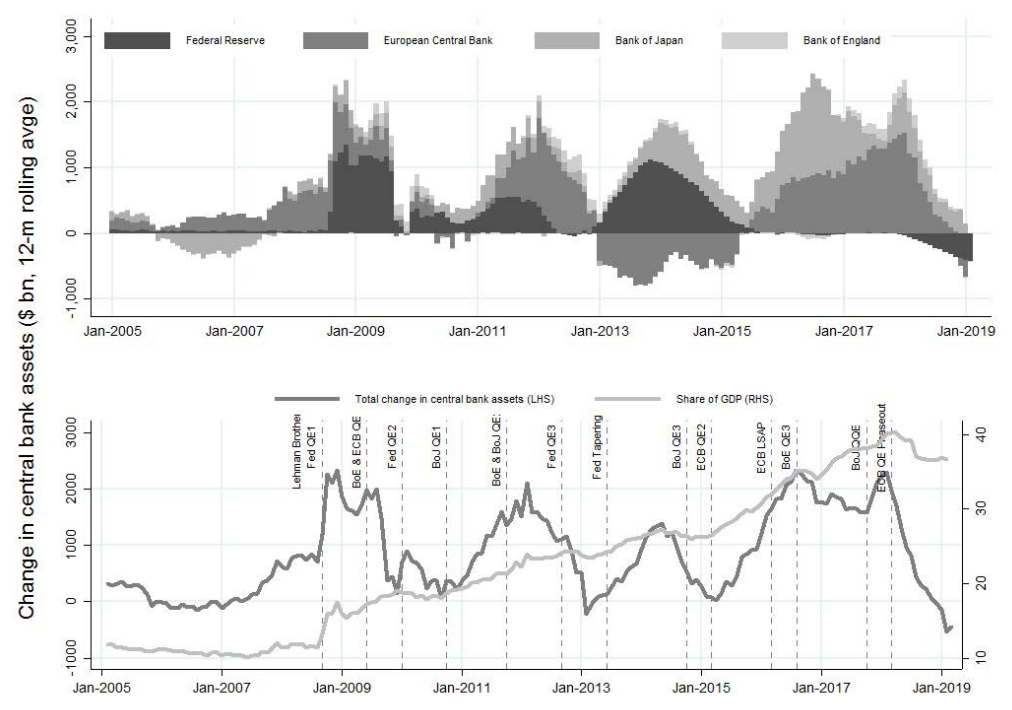

Figure 22.1 Quantitative easing and balance sheets.

Notes: Monthly changes of central bank assets are averaged over a 12-month rolling window to smooth volatility due to operational characteristics that vary by institution.

Sources: Author's calculation from IMF and individual central bank data.

network of central bank lending facilities in the form of currency swaps lines that is anchored by the C5 and the Bank of Canada at its institutional core. This global swaps network now covers over 70 separate agreements involving over 50 central banks, thus establishing "an elastic backstop of an international monetary system that remains very much a dollar system... for private foreign exchange operations" (Bernes et al., 2014: 3). On the periphery of this system, a further network of central bank swaps "operates to economize on scarce reserves of the major currencies" (Mehrling, 2015: 311).

With central bankers being active on such a large scale and in such a globally coordinated manner, while facing so little democratic accountability, the specter of a technocratically governed IMS - a ghoul that most thought had died with the collapse of the Bretton Woods System during the 1970s—had risen once again. Wielding clubs of massive balance sheets and parading a new arsenal of unconventional monetary policy tools, the 'Lords of Finance' had staged an impressive return (cf.Ahamed, 2009). Their forceful display of control at the helm of the post-crisis IMS has infused the term 'unelected power' with new meaning and urgency. Indeed, this bold re-assertion of a resource-rich regulatory state has added a healthy dose of complexity to the all-too-simplistic narratives of hollowed-out government and austerity in the age of neoliberalism (Tucker, 2018). What began as a 'state of monetary-financial exception' 
has now matured into a 'new normal'. In short, in the decade after the GFC, central bankers have become more firmly established as the institutional apex of the modern monetary system than at any point in the post-war era.

In light of these developments, this chapter examines the evolving role and function of central banks in the post-crisis geography of money. One of the central perspectives taken here focuses on the fact that the IMS is at once hierarchical in finance and hierarchical in power, and that central banks play a pivotal role in this hierarchy. In fact, I argue that this role of central banks is best captured in the governance of what we will define as 'monetary space'; that is, an abstract economic space in the sense of François Perroux (1950a, b) that is spanned by financial markets, financial instruments, monetary-financial intermediaries, non-bank financial institutions, publicly sponsored intermediaries, and, of course, central banks. According to Perroux:

[a] monetary space as defined by a plan... is formed by the relations which constitute the plan for the employment of money....Monetary space as a field of forces... is seen in terms of a "network" of payments, or by means of the description of monetary flows.... Monetary space as a homogenous aggregate suggests an almost perfect international currency market and an approximate unity in exchange rates.

(Perroux, 1950b, pp. 97-9; emphasis in the original)

Expanding the Perrouxian perspective, this chapter takes a closer look at the different dimensions of monetary space and the role central banks are playing in the governance of each of these realms. Moreover, the crucial role that central banks fulfil as the institutional in global monetary spaces is inherently hierarchical in an operational and functional sense. As such, this chapter argues that central banks critically shape three fundamental relationships among constituent economic elements in the Perrouxian system: (i) monetary space as defined by a plan; (ii) monetary space as a field of forces; and (iii) monetary space as a homogeneous aggregate.

This chapter also engages with the rapidly expanding post-crisis literature on the 'economic geography of money and finance', and argues that, despite an enthusiastic re-engagement with money and finance in the decade after the GFC, central banks and monetary space plays no more than a perfunctory role in this literature. Consequently, much of this rapidly expanding literature tends to remain singularly faithful to locational and agglomerational aspects of what Perroux (1950b) termed "banal economic space" wherein the true monetary power of central banks is difficult to analyse. In doing so, the contemporary canon of geographical economists still enshrines the classical dichotomy, which moves the spheres of money beyond the microeconomic mechanics of analysing the realm of production. As such, the treatment of money in economic geography has only just begun to take the 'macro-effects of central banking' 
seriously (cf. Bieri, 2019a; Mann, 2010, 2012). This chapter hopes to contribute to a new research agenda that such an engagement would entail.

The remainder of this chapter is structured as follows. After an outline of some of the key elements of monetary space and central bank governance, I turn to a discussion of the different dimensions of monetary space in a Perrouxian sense, paying particular attention to constituent subspaces, namely 'currency space', 'regulatory space' and 'policy space'.

\section{Central Banks and the Monetary Hierarchy}

Given the dramatic changes to central banks' policy environment after the crisis, it is not only important to provide a larger contextualization of how these developments sit within the IMS, but also how the central bank-as the institutional of the monetary hierarchy-is linked via its balance sheet to the rest of the monetary system. Indeed, the GFC has driven home the importance of financial flows and the composition of sectoral balance sheets for an understanding of real-financial linkages. ${ }^{5}$

As Minsky (2008:) famously reminds us, the key to the flow of funds perspective is to look at all actors in the economy (households, firms, governments, including central banks, and the financial sector) as if they were banks. As such, each entity has a balance sheet of cash inflows and cash outflows, and each is bound by the 'survival constraint'; that is, the requirement that cash outflows not exceed cash inflows. The money flow economy then arises in aggregate from the interconnection of all balance sheets which, in turn, gives rise to the fundamental instability of a credit economy (Minsky, 1977, 1993). The money flow economy is the basis for a flow-of-funds accounting view which-as an analytical approach - provides a unique characterization of how financialization has progressively reshaped the modern macroeconomy through the process of financial globalization.

The process of financialization has thus completely intertwined the monetary system with the financial system such that we cannot talk about money without talking about finance. This raises the importance of several institutional hallmarks of the current system. At its core, there are the wholesale money markets as the central funding mechanism, with 'shadow banks' - that is, non-bank financial intermediaries that provide services similar to traditional commercial banks but that reside outside normal banking regulations - as key institutions that facilitate short-term funding of long-term lending. Given the importance of these flow-based changes to the relevance of the inner workings of the monetary-financial system, the need arises for refocusing the discussion in conceptual terms. The most important concepts in this regard are the (international) monetary hierarchy and the central bank's balance sheet.

Among one of the most central characteristics of the modern monetary system is its hybrid and hierarchical nature, at both the national and international levels. Its hybridity comes from the fact that it is part public (it involves 'outside 
money') and part private (it involves 'inside money'). 'Outside money' is either of a fiat nature or is backed by some asset that is in positive net supply within the private sector (e.g., gold), whereas 'inside money' is an asset backed by any form of private liability (credit) that circulates as a medium of exchange. While this analytical distinction was first introduced over half a century ago (Gurley and Shaw, 1960), it has only recently been augmented by work that explicitly emphasizes the hierarchical relationship between public and private liabilities that circulate as money (Bell, 2001; Mehrling, 2013).

With regard to this hierarchical nature, it is important to highlight that money is not only hierarchical in finance, but also hierarchical in power (e.g., in the Federal Reserve's ex post definition of what is adequate collateral and its inherent role as the 'market maker of last resort', Mehrling, 2011). In the context of the IMS, the hierarchy in power plays a particularly important role with regard to the uneven 'international moneyness' of different national currencies. Indeed, as Keynes has already contended, the monetary side of the (global) economy anything but neutral. ${ }^{6}$ To the contrary, in part because of its hierarchy, episodes of international financial instability are-at their very core-the results of the varying degrees in 'international moneyness' that make currencies unequal (Terzi, 2005). In this regard, the GFC was no different.

The upper portion of Figure 22.2 illustrates the hierarchy of money at the national level, where money and credit are created by different financial institutions at separate levels of the hierarchy (left to right). For simplicity, we only show instruments discussed so far, leaving out government debt as the most important asset of the central bank (see lower portion of Figure 22.2, for a more complete characterization of a central bank balance sheet), loans as an asset of the banking system, and the entire 'shadow banking' system. Note that all of the instruments except gold (and FX reserves) appear as both assets and liabilities. ${ }^{7}$ Because they are all forms of credit, they would all cancel out if we consolidated the three balance sheets into one in order to treat the economy as a single aggregate entity. Only gold and FX reserves would remain and only gold is an asset that is no one's liability - the very definition of 'outside money'. The monetary pyramid thus arises because of such credit-based linkages across sectoral balance sheets.

As we have seen, the central bank sits at the apex of the pyramid and connects the national system to the IMS. The hierarchy of money can thus be read both institutionally and, perhaps more importantly, in a functional manner; that is, in terms of what constitutes money and credit as an accepted means of settlement. A central feature of view is the fact that the distinctions between money and credit are not strict, and largely depend on the specific vantage point from within each layer of the system. At the top of the hierarchy, gold and deposits at the central bank are the 'ultimate money' because they are the ultimate means of international payment. To see why this is the case, we need to examine the monetary hierarchy 'in action' by discussing the mechanics of cross-border 
David S. Bieri

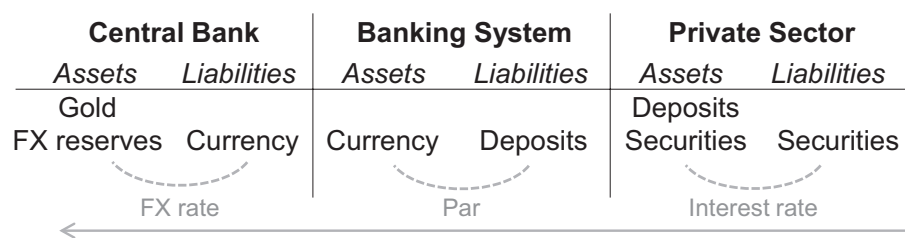

\begin{tabular}{c|c}
\multicolumn{2}{c}{ Central Bank } \\
Assets & Liabilities + capital \\
\hline Net international assets & Reserve money \\
Gold, SDR & Currency in circulation \\
Foreign exchange reserves & Reserves of commercial banks \\
Net domestic assets & Non-monetary liabilities \\
Cash & Central bank securities \\
Bank loans & Others \\
Securities (OMO) & Equity capital
\end{tabular}

Figure 22.2 Hierarchy of money and balance sheets.

Notes:The relative prices that define the hierarchy of money are the FX rate ('price of currency' in terms of gold, or foreign currency; i.e., the FX rate can be thought of as a relative price of converting one currency into another or gold). Similarly, par can be thought of as the "price of deposits' in terms of currency (i.e., the cost of converting a deposit into cash) and the interest rate as the 'price of securities' in terms of deposits or currency. OMO: open market operations. Sources: Author's illustration, adapted from Bieri (2000), Caruana (2012), and Mehrling (2013).

payments that appear - to the naked eye, at least—-simply to rely on transfers of bank deposits (or physical movements of cash). Before we do this, however, let us also consider the related fact that currencies, both international money and national money, are deemed a form of credit insofar as they are promises to pay gold or central bank (fiat) money. Similarly, further down the hierarchy, bank deposits are viewed as a form of private credit money-effectively, promises to pay currency on demand and thus twice removed from the promises to pay ultimate money. Private money in the form of debt obligations (IOUs) or securities is, then, a promise to pay currency or deposits over some specific time horizon.

A second crucial feature of this hierarchical view of money lies in the fact that, at each layer of the system, the 'moneyness of credit' depends how easy it is to convert a specific form of credit into the next higher form of money (e.g., deposits into currency, or currency into gold). In other words, what counts as money and what counts as credit depends on the layer of the hierarchy under consideration, and on what counts as the ultimate means of settlement. This brings us right back to how gold and central bank deposits, not bank deposits, act as 'ultimate money' for cross-border payments. A brief look at the 'credit mechanics' across the hierarchy of money should help to clarify this point. 
Consider the payment flows in the case of Firm A, a German supplier of industrial robots located $50 \mathrm{~km}$ northwest of Munich, selling a new assembly system for say, €10 million, to Firm B, a large Spanish car manufacturer located $25 \mathrm{~km}$ northwest of Barcelona. On the surface, the money flow equivalent of this transaction appears to be a simple direct transfer of deposits from the Spanish bank account of Firm B to Firm A's account at its German correspondent bank. Behind the scenes, however, the hierarchical nature of money as outlined above implies that Firm B's commercial bank will see its reserve account at the Banco d'España (an asset on the commercial bank's balance sheet) reduced by $€ 10$ million, and it will see Firm B's deposits (a liability) reduced by $€ 10$ million. The receiving commercial bank in Germany will see corresponding increases in its reserve account at the Bundesbank and in its customers' deposits. Just as both commercial banks have balanced changes in assets and liabilities, so do both Eurozone central banks. The Banco d'España's reserve account liabilities decrease by $€ 10$ million, the Bundesbank's reserve account liabilities increase by $€ 10$ million, and the offsetting changes on the asset side of the Eurozone central banks' balance sheets occur through their respective accounts in TARGET2, the interbank settlement and payments system of the European Monetary Union (EMU). ${ }^{8}$ Because the Banco d'España is effectively making a payment to the Bundesbank, its TAR GET2 balance (an asset) falls by $€ 10$ million, and the Bundesbank's TARGET2 balance rises by $€ 10$ million. The ultimate settlement of this transaction thus happens in terms of 'central bank money', not 'commercial bank money'.

As we have seen, then, the notion of monetary hybridity implies that the credit pyramid oscillates between a condition where money is 'scarce' and one where credit is 'elastic' (Mehrling, 2013). In this regard, one of Minsky's (2008) key insights was that the hierarchy of money shifts across the economic cycle through three distinct phases: hedge finance, speculative finance, and Ponzi schemes. Money and credit are thus fluctuating between states of elasticity and states of discipline. In this context, central banks determine the institutional plane within which the monetary-financial pendulum swings across monetary space.

\section{Conceptualizing Monetary Space}

As a next step, we must therefore engage in more detail with the conceptualization of monetary space as an analytical abstract. A central feature of such a move lies in distinguishing between physical and functional notions of space, a distinction that was first introduced to the analysis of the space-economy by Perroux's (1950a, b) re-theorization of economic space around a set of "(economic) plans", "field forces", "homogenous aggregates" and "domination effects" between them. Such an abstraction primarily privileges "spaces of flows" over the more conventional notion of "spaces of places". In many ways, such a reconfiguration of the spatial relations of money and finance can be read 
as being consistent with what Thrift and Olds (1996: 314) envisage-in the Perrouxian sense described above-as a "transformative re-conceptualization of the remit of economic". In this very spirit, Leyshon and Thrift (1997) and Martin (1999) provide the first broader conceptualizations of and engagements with monetary space as an analytical abstract. Similarly, French et al. (2011) suggest that research on financializaton has been insufficiently attentive to network- or flow-based notions of economic space. Yet, none of this work connects back to Perroux's pioneering inquiries.

In fact, of all abstract economic spaces, Perroux places particular emphasis on monetary space as a field of forces in terms of "a 'network' (in the mathematical sense) of payments, or by means of the description of monetary flows. A center (or pole) has then to be chosen, from which one draws the 'network' of payments towards or from other centres; or from which emanate, and to which come, monetary flows. The most significant of these 'centres' are complex aggregates of monetary and financial organisms-the 'places"' (Perroux, 1950b: 98). In Perroux's analysis, monetary space is simultaneously delocalized, yet inherently hierarchical, operating at several levels of "banal space" (i.e., at the regional, national, and global scales). ${ }^{10}$

As such, the discourses on the monetary geography are centered around what Cohen (1998) terms a 'flow-based model of currency relation', where networks and hierarchies form the primary units of analysis, all within a largely de-territorialized spatial organization of monetary-financial relations. Instead of dealing with money and central banking in what Perroux termed "localized banal space", (i.e., where space is simply the 'genomic relations between points, lines, surfaces, and volumes'), I want to conceptualize monetary space as a 'delocalized space' in the abstract sense.

Thus, instead of using conventional definitions of space as the "disequilibrating frictions" that give rise to agglomerational phenomena, economies of scale and other distance-based spatial effects, Perroux's abstract spaces are characterized by power relations and domination effects that impinge on "the plan of units" and that regulate "the relations of a homogenous aggregate relative to the unit". And finally, Perrouxian spaces are economic force fields that both "emanate from units" and "act on units"; that is, these spaces are pinned down by "centres (or poles or foci) from which centrifugal forces emanate and to which centripetal forces are attracted. Each centre being a centre of attraction and repulsion, has its proper field, which is set in the fields of other centres" (Perroux, 1950b: 95) In short, monetary space thus conceptualized is not the locus for financial localization effects between economic actors per se, but the money-based force fields and power-relations between economic actors. It is in this precise sense that I want to analyse the role of central banks in the governance of monetary space.

Specifically, we can now conceive of monetary space along three nested dimensions ('policy space', 'regulatory space', and 'currency space'), or subspaces, for each one of which the central bank acts as a key institutional pole. Figure 22.3 presents a schematic illustration of these monetary subspaces and the 


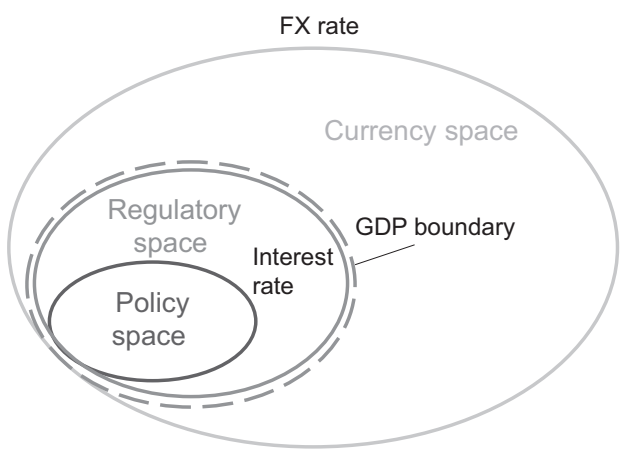

Figure 22.3 Dimensions of monetary space.

Notes: Policy space ('defined by plan'), regulatory space ('defined by homogeneous aggregate') and currency space ('field of forces'). This synoptical approach to monetary space follows Perroux (1950b), where every set of relations constitutes an abstract space in the Perrouxian sense.

Source: Author's illustration.

relationship between them, particularly with regard to the policy instruments that are under the control of central banks. At the central core of monetary space, there is 'policy space' wherein the central bank regulates the economic relationship and economic 'plans between units' by regulating the intertemporal price of money; that is, interest rates. While the central banks have conventionally exerted direct control over interest rates via their short-term policy rates, the secular decline of the policy rate towards the zero lower bound in the wake of the GFC has demonstrated the importance of central banks indirect control over longer-term interest rates by affecting quantities, rather than prices, as was the case in QE policies. Policy space is thus spanned by the extent and nature of how the transmission mechanism of monetary policy acts on the plan of economic units. From the availability of interbank lending to the price of residential mortgages, central banks sit at the very center of this monetary subspace. As will be discussed, the rapid digitization of money on the back of distributed-ledger technology (DLT) is posing a new set of unprecedented challenges over the control of monetary space in general and over policy space, in particular.

'Regulatory space' forms but distinctly separate, monetary space wherein central banks regulatory and supervisory activities can be thought of as regulating the economic relations of an aggregate "relative to the units and to their structure, or relative to the relations between these units" (Perroux, 1950b: 96). Specifically, we could think of regulatory space as the structure of the regulatory system that in important ways influences the roles played by the various components of the monetary-financial system (financial instruments, financial markets, monetary and financial intermediaries) in promoting the inter-regional mobility of funds and, by extension, the mobility of funds among the various sectors of the space economy. ${ }^{11}$ Rapid economic and financial globalization 
notwithstanding, central banks' control over the governance of both policy and regulatory space is still bound by the political boundaries of the nation state. In many ways, national central banks provide the most powerful national lever for leaning against the winds of economic globalization.

Lastly, then, we define 'currency space' as the Perrouxian monetary subspace that is spanned by competing national currencies in a constantly evolving 'field of forces' wherein national currencies vie for global dominance. Whether this is "in one case, a dominant national currency, and in another, a currency dealt with by a number of places of comparable power and harmonizing policies" (Perroux, 1950b, p. 99), both central banks that issue the currency and financial centers within which the currencies are traded are important nodes that shape the global network of currency spaces. Figure 22.4 attempts to visualize such
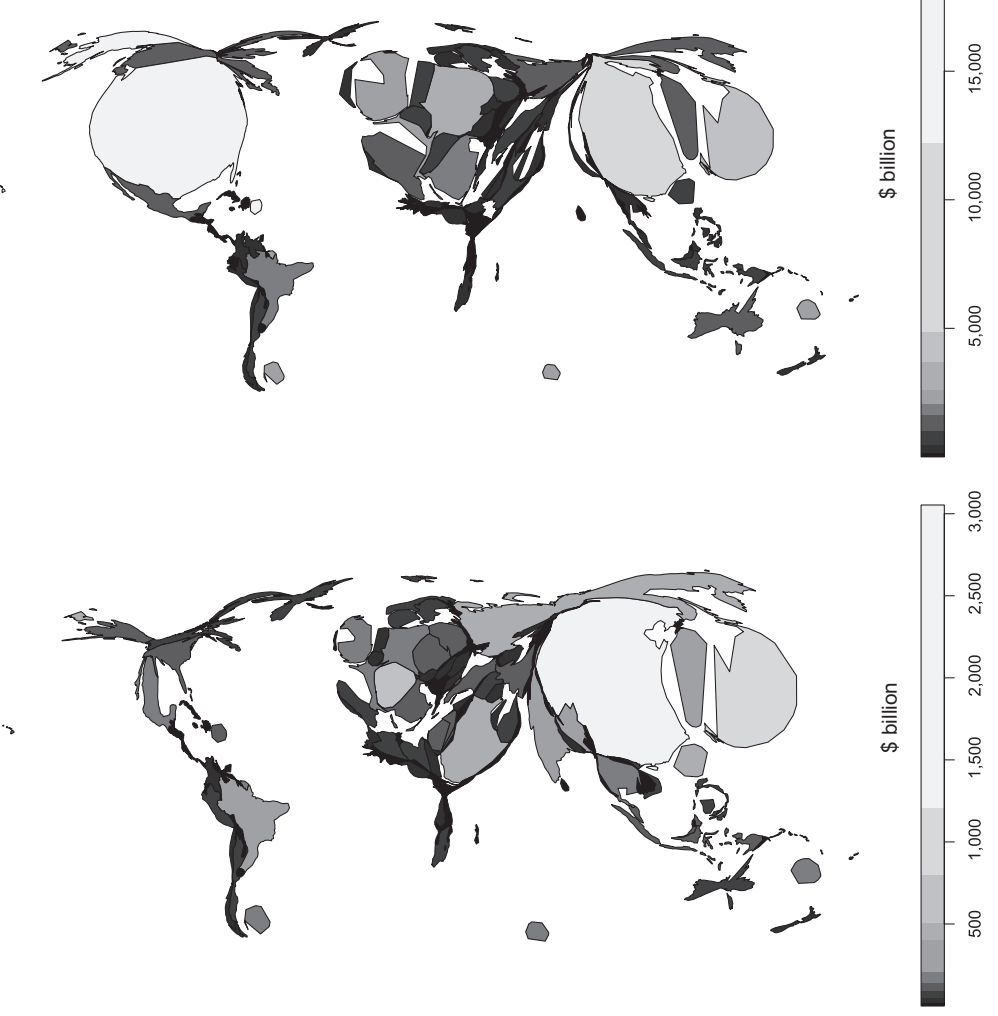

Figure 22.4 FX reserves and the shaping of currency space.

Notes:The cartograms use GDP (top) and nominal foreign exchange reserves (bottom) as scaling variables.

Sources: Author's calculation from BIS and IMF data. 
Central Banks and the Governance of Monetary Space

Table 22.2 Central Banks, Policy Instruments, and Monetary Space

\begin{tabular}{|c|c|c|c|}
\hline $\begin{array}{l}\text { Type of monetary } \\
\text { space }\end{array}$ & Character & Instruments & $\begin{array}{l}\text { "Domination effect" } \\
\text { (CB control) }\end{array}$ \\
\hline Policy space & "defined by a plan" & $\begin{array}{l}\text { Monetary policy (interest } \\
\text { rates, asset purchases) }\end{array}$ & High \\
\hline $\begin{array}{l}\text { Regulatory } \\
\text { space }\end{array}$ & $\begin{array}{l}\text { "defined by a } \\
\text { homogenous } \\
\text { aggregate" }\end{array}$ & $\begin{array}{l}\text { National banking } \\
\text { regulation, international } \\
\text { supervisory standards } \\
\text { (e.g., Basel Accords) }\end{array}$ & Medium \\
\hline Currency space & $\begin{array}{l}\text { "defined by a field } \\
\text { of forces" }\end{array}$ & $\begin{array}{l}\text { International currency } \\
\text { competition, exchange } \\
\text { rate arrangements } \\
\text { (fixed, floating) }\end{array}$ & Low \\
\hline
\end{tabular}

Note: See text, for more details.

a force field-based version of global currency space in an semi-abstract sense, whereas Table 22.2 summarizes our conceptualization of aggregate monetary space along its most important dimensions.

For all their analytical distinctness, it is also clear that the three types of monetary spaces share large areas of mutual dependence and overlap (as is, indeed, implied in Figure 22.2). For example, in an open economy, policy-makers are often seen as constrained by the so-called 'monetary policy trilemma', which imposes stark trade-offs across the three monetary spaces, specifically exchange rate stability (currency space), monetary independence (policy space), and capital market openness (regulatory space). Specifically, the trilemma-which is sometimes also referred to as the 'impossible trinity'-implies that a country cannot simultaneously achieve a fixed exchange rate, independent monetary policy, and free capital flows. While it is mostly unchallenged that countries can still choose only two out of the three policy goals, increasing capital mobility appears to have changed the policy consensus about the relative weight given to each of them; namely, that the exchange rate needs to adjust more flexibly than in the past (see, e.g., Obstfield, Stambaugh, and Taylor, 2010). The sharp rise in central bank holdings of foreign exchange reserves since the 1990s, however, seems to tell a very different story. In the context of the recent financial crisis, the trade-offs implied by the trilemma have once again risen to the very top of policy-makers' agendas; yet, in contrast to previous episodes of financial instability, burgeoning central bank reserves and the emergence of sovereign wealth funds are viewed as challenges to-rather than possible solutions for-a redesign of the architecture of the global financial system.

Moreover, across all monetary spaces, central banks exert varying levels of control over other economic actors within a given monetary space. This, in turn, gives rise to a multitude of what could be described as "monetary 
domination effects', which we define by simply extending to our setting of monetary spaces Perroux's definition of a situation when "unit A exercises on unit B an irreversible or partially irreversible influence" (Perroux, 1950a: 188). However, in each of the monetary spaces, the nature of the domination effect is a function of the central bank's power within that space. The strength of the domination effect of central banks is largest in the 'policy space' because of its tight control over monetary policy instruments, old and new. It is 'medium' in regulatory space due to the variegated nature of institutional regulatory and supervisory mechanisms, many of which often lie outside the direct control of the central bank. The strength of the domination effect is weakest in the 'currency space', which is largely due the hybrid nature of the global monetary-financial system. This implies that every central bank that issues an 'internationalized currency' shares its institutional control over the corresponding 'currency space' with internationally active private depository institutions that operate out of global financial centers such as London, Tokyo, or Zürich. ${ }^{12} \mathrm{We}$ will now turn our attention to how this two-tiered control over currency space in the eurodollar market has given rise to a new geography of money.

\section{The New Geography of Money}

Tracing out the evolution of monetary (sub)spaces in historical perspective, this section engages with the geographic shifts in the global structure and governance of various 'currency spaces' in general, and the changing nature of the IMS, in particular. Indeed, the history of modern capitalism has seen two versions of the IMS; first, the sterling era that lasted until World War I, and then the dollar era, which has been in effect since. From a functional perspective, these two eras were accompanied by the gradual evolution of the IMS from a commodity (gold)-based system into a credit system. In the context of our previous discussion about the hierarchical and hybrid nature of monetary space, the important point to appreciate here is that international money has typically been a "promise to pay some national money, the issue of a specific reserve currency nation state. The key institutional mechanism for extending national into international money has been the growth of international financial centers (in London for sterling, in New York for dollars) to support the emerging globalization of trade, production and finance" (Bernes et al., 2014, p. 8, emphasis added).

Today, the undisputed international money is (still) the dollar-in particular, the eurodollar (i.e., dollar-denominated deposits of non-US banks that are held overseas by non-US customers and that are used to finance dollar loans and securities issued by other non-US customers). Eurodollars emerged with the Marshall Plan after World War II when vast amounts of dollar funds were circulating across war-torn Europe in the custody of foreign banks outside the direct control of US monetary authorities. Because they are held outside the United States, eurodollars are not subject to regulation by the Federal Reserve, 
including reserve requirements and deposit insurance, which added to their rapid growth in the post-war environment. At the same time, cost-push inflation and US budget deficits in the wake of the collapse of the Bretton Woods system further dampened the international attractiveness of the 'on-shore' dollar such that, by the early 1980s, eurodollars had overtaken certificates of deposit (CDs) issued by US banks as the primary private short-term money market instruments. As such, the singular role of the 'dollar space'-both onshore and offshore-remains a symbol and a source of strength for the US economy, despite the fact that the Federal Reserve actually only exerts very weak direct control over this part of its 'currency space'. To some, these are all developments that characterize the first stage of a 'new geography' of the post-Bretton Woods order (Cohen, 2003; Helleiner, 2010; Subacchi, 2010).

In the second stage of this geographic transformation, the IMS has seen the creation and rise of the euro as a reserve currency, and the unprecedented, politically engineered internationalization of the Chinese renminbi. ${ }^{13} \mathrm{In}$ fact, in the decade before the GFC, the 'new geography of money' reached its climax as currencies were becoming, at once, more de-territorialized in their international use ('currency internationalization') and were under more intense competitive pressure from foreign-issued currencies in their domestic use ('currency substitution'). In the setting of this new geography, states were developing new modes of monetary governance that increasingly mirrored the process of 'marketization' that was taking hold in other realms of economic governance. More and more, realms that were hitherto the traditional province of state power have become reliant on markets and private institutions.

Yet, for all its geopolitically convincing appeal, this multilateral transformation of the IMS may have, as Mehrling (2015) argues, less to do with changing international relations between states than it has to do with commercial relations - and, hence, payment systems and liquidity — between national financial systems. Nevertheless, it is clear that the commercial logic of this increase in currency competition was ultimately shaped by large historical-political shifts that were set in motion by the collapse of Bretton Woods, and then intensified by fall of the Berlin Wall, the creation of the EMU, and the rise of China (Clark, 2015; Helleiner, 1994).

Symptomatic for these developments in global currency trends was the slide of the hegemonic role of the US dollar as the reserve currency of choice. In 1973, the year when the Smithsonian Agreement officially rang in the post-Bretton Woods era, close to $80 \%$ of global foreign exchange reserves were denominated in dollars, and the rest mostly in pound sterling with some euro legacy currencies (i.e., the Deutsche mark and French franc). By the 1990s, after a decade of concerted currency interventions by the G7 central banks in the Plaza and Louvre Accords, the dollar's global share in official reserve portfolios had fallen to under $60 \%$. But, since the beginning of the new millennium-when international reserves began their explosive growth, which has slowed down only recently — the dollar share in central bank reserves has 


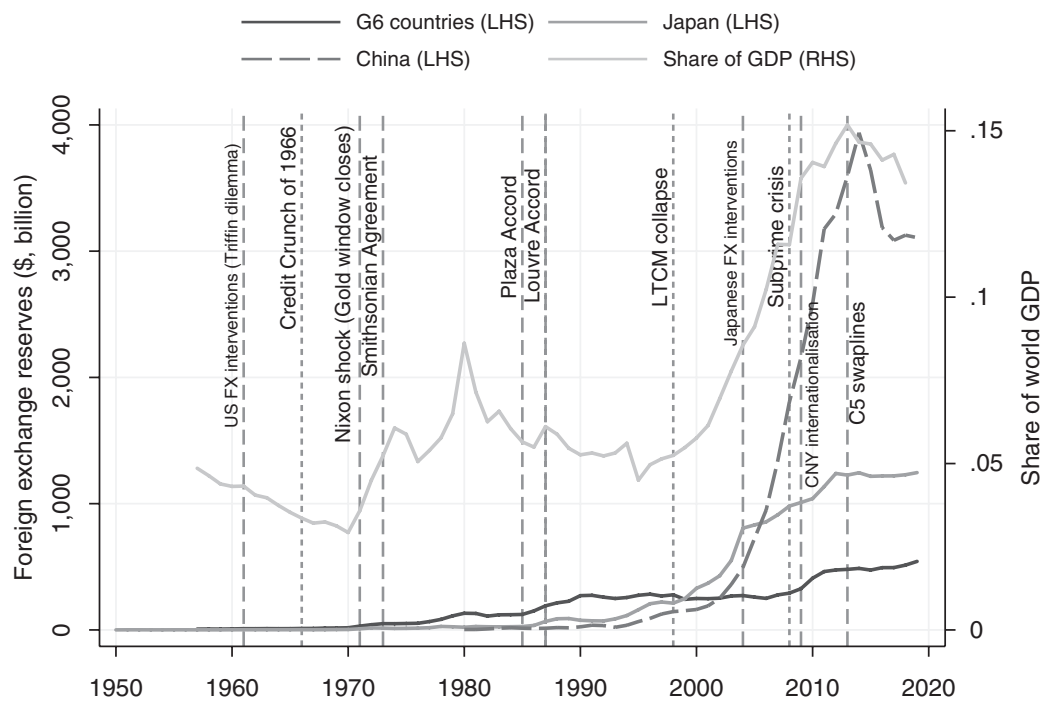

Figure 22.5 The IMS and the growth of global foreign exchange reserves.

Notes: Vertical lines denote important events in the governance of the international monetary system (long dash) and financial crises (short dash).

Sources: Author's calculations from IMF and BIS data.

bounced back to around two-thirds of official holdings. Today, close to US $\$ 7.1$ trillion of the approximately US\$11.2 trillion of reserves are denominated in dollars. At US $\$ 2$ trillion, the euro is a distant second, with yen and pound sterling sharing about half the balancing amounts. Figure 22.5 illustrates the transformative growth of global foreign exchange reserves across various postwar stages of the IMS.

And it is not only in foreign exchange reserve holdings that the dollar has been able to maintain its dominant position. While the years in the run-up to the GFC may have given the impression that the IMS was moving toward a multicurrency system with several poles, the crisis certainly has unambiguously reversed this trend, at least for now. As Figure 22.6 highlights, the evolution of 'international currency space' as measured by the force field of currency shares in foreign exchange market turnover shows the domination effect of US dollar anything but weakening. Indeed, even the most recent evidence on the size and structure of global foreign exchange markets-the 2019 BIS Triennial Survey-confirms that there still is only one true pole in the IMS: the US dollar. The euro is lagging behind considerably and the yen, pound sterling, and Swiss franc are, at best, niche players (Cohen and Benney, 2014). For much of the political importance of its arrival on the world stage as a convertible international currency a decade ago, the renmimbi's presence is barely noticeable 


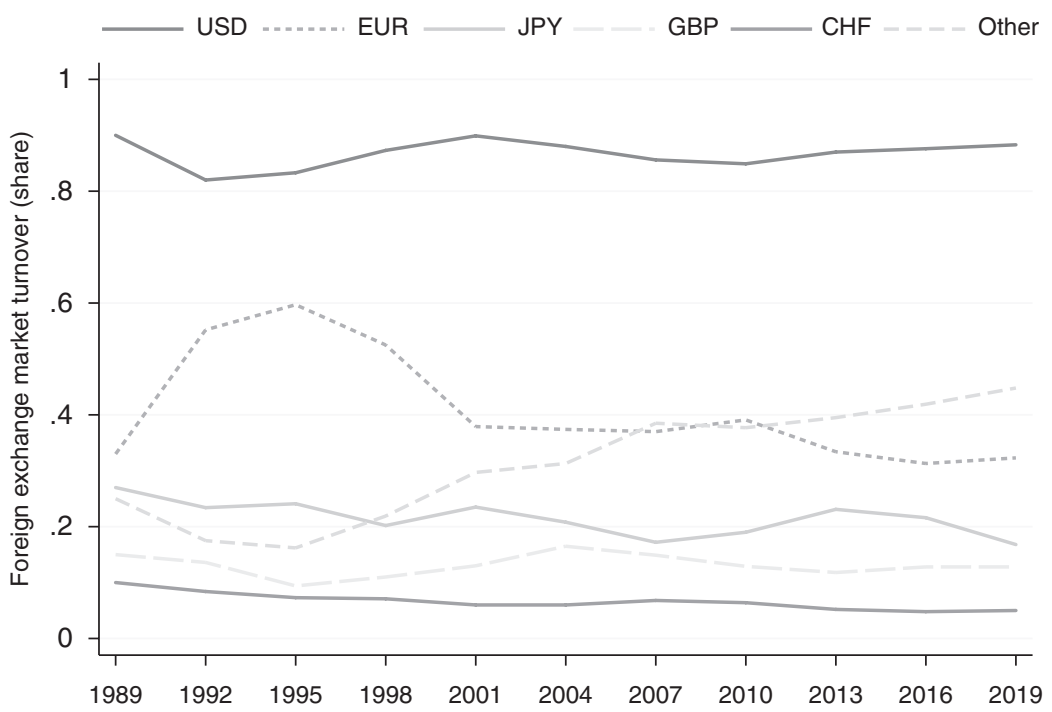

Figure 22.6 Currency shares in foreign exchange market turnover.

Notes: As two currencies are involved in each transaction, the sum of shares in individual currencies will total $200 \%$.

Source: Author's calculations from BIS Triennial Survey data (BIS2019b).

yet. In light of recent developments, the question remains under what circumstances the euro and the renmimbi may perhaps come to rival the dollar, and how such increased currency competition could affect global financial stability (e.g., Eichengreen et al., 2017; Kirshner, 2014).

At the same time, the financial crisis has also led to a certain amount of re-territorialization of the discourse on the spatial consequences of finance as regulatory responses to the crises-from bailouts to the creation of new regulatory arrangements - almost invariably took place within the institutional framework of nations. Yet, this re-territorialization is not simply a reversion to the realities of the 'old geography', with competing nation-states and clear urban hierarchies as the key spatial units of interest. Instead, it is an emergent new arrangement where globally dispersed creditors and debtors are the main actors (Bieri, 2009). Within this new geography, the traditional roles and interactions between borrowers and investors are being reconstituted with regard to both their spatial and their institutional organization. While the monetary and financial aspects of this new spatial order still assign states significant control over their 'regulatory space', the political governance of the Westphalian system has been replaced by a new geography of globalized currency relations (Cohen, 2007). And in this market-based arrangement, states only exert modest direct control over 'currency space'. 
In tracing out the historical evolution of international 'currency spaces', our discussions of a hierarchy of globalized money that has the US monetary-financial system at its core immediately render visible this monetary hierarchy-monetary space nexus; that is, the connection between the monetary hierarchy and the different dimensions of monetary space. While we have focused on this nexus in the context of 'currency space', it is clear that the structure and function of 'policy and regulatory space' are also closely linked to the institutional evolution of its monetary hierarchy. Put differently, in the same way that the interplay between the hierarchy of the IMS maps into currency space, we could show that there is an analogous relationship that has shaped the evolution of US policy space and regulatory space.

At the heart of this connection lies a process that I refer elsewhere to as the 'regulatory-spatial dialectic' - a mechanism that operates through the vectors of financial integration, economic agglomeration, and suburbanization, setting in motion spatio-temporal processes that continuously reconstitute monetary space across the economic cycle. Its detailed institutional elements and linkages are discussed in greater detail elsere (Bieri, 2017, 2018). For our purposes, here it will suffice to remark that-analogous to the force fields that have shaped the historical trajectory of the IMS - the evolutionary interplay between markets, institutions, and the state initiate dialectical processes of adjustments and counter-adjustments with respect to monetary governance and financial regulation. In the following section, we will turn to the most current stage in this process: the radical transformation of monetary space through the inexorable rise of digital monies, both private and public.

\section{The Digital Struggle over Monetary Space}

The digitization of money has come to present one of the most unique challenges to central banks in their modern history. The rise of cryptocurrencies and the prospect of central bank digital currency (CBDC) are set to redefine the shape and forms of control over monetary space in unprecedented ways. This institutional disruption is perhaps at its most acute in policy space where crypto assets will transform the monetary transmission mechanism, possibly even undermining central banks' century-old monopoly of providing the official unit of account. In this section, I will argue that the very same lens of our spectrum of dominance effects introduced earlier will provide useful insights in analysing this new reality of digital monetary space. In fact, 'cryptocurrencies' writ large readily present a number of challenges along Perrouxian dimensions, particularly with regard to their impact on both 'policy space' and 'regulatory space'.

What is commonly referred to by the term 'cryptocurrencies' are new forms of financial instruments that often rely on distributed ledger technology (DLT) that most commonly runs on a public (permissionless) or private (permissioned) blockchain. Aside from all the 'tech' excitement that comes with the 
possibilities of disruption in the current 'FinTech moment', we therefore also need to examine the 'Fin' element a little more closely. ${ }^{14}$ In fact, financial regulators, such as the SEC, the Federal Reserve, or the OCC, prefer to use the term 'cryptoassets', because these DTL-based products-from BitCoin, Etherium to the rapidly expanding class of stable coins (including Facebook's prospective Libra) - are really a new class of financial instruments that are based on the issuance of private digital tokens either for general payment or wholesale purposes. The monetary space of privately issued cryptoassets is a fiercely competitive environment and, for all the promises of a grass-roots revolution, in many instances, it is not entirely clear what the value proposition of a number of these new 'monies' really is. Are many of them simply still the proverbial solution looking for a problem, and how should that then translate into intrinsic value? This is a very broad topic, well beyond the scope of this chapter, but, in the context of our discussion of monetary space, we can reduce it to the question of the extent to which digital money transforms the role of money in a system of finance-led capitalism.

With regard to the impact on 'policy space', privately issued cryptoassets that can be used for payment purposes fundamentally challenge the monetary hierarchy because they are-like gold — the ultimate 'outside money'. In other words, they are nobody's liability but, unlike gold, they can be produced at the 'push of a button'. Indeed, while many of the cryptoassets may pretend to be currencies and make varying claims about their 'moneyness', they invariably fail the basic textbook definitions of what constitutes sound money (unit of account, means of payment, store of value). Most would agree that they do not function as a unit of account. Their volatile valuations make them unsafe to rely on as a common means of payment and a stable store of value. They also defy lessons from theory and experiences. Most importantly, given their many fragilities, cryptocurrencies are unlikely to satisfy the requirement of trust to make them sustainable forms of money. Thus, while new technologies have the potential to improve economic well-being, this is not invariably the case (Carstens, 2018, 2019a, b). Indeed, concerns over the ability of this outside money to serve as a reliable unit of account have been illustrated in a very tangible manner in the context of the spectacular bursting of the BitCoin bubble which began in early 2018. While BitCoin is an incredibly important 'proof of concept' for blockchain technology applied to payments, economists agree that there is no reason why BitCoin should have an intrinsic value (Dwyer, 2015; Schilling and Uhlig, 2019). These issues aside, to some, algorithmic digital currencies still appear to be viable competitors to central bank fiat currency. And, as such, they thus fundamentally challenge central banks' control of 'policy space' and threaten an unprecedented flattening of the monetary hierarchy.

As a response to this potentially existential challenge, central banks themselves have started actively embracing the possibility of DLT-powered CBDC, which not only promises to improve central banks' payment and clearing operations, but would also allow them to cement, and even extend, the strength of 
their dominance effect in this monetary subspace. In fact, a sovereign digital currency could have profound implications for the banking system because it obviates the need for the public to keep deposits in fractional reserve commercial banks. The prospect of CBDC would thus radically tighten, but not flatten, the monetary hierarchy by narrowing the relationship between citizens and central banks (Raskin and Yermack, 2017; BIS, 2020). And, as a consequence, central banks' dominance over policy space could become even 1 grer! Indeed, recent evidence from a survey of over 60 central banks around the globe shows that, while most central banks are only at a conceptual stage with regard to CDBC, a handful of central banks are already poised to issue a digital currency in the short or medium term (Bartorini and Holden, 2019).

By the impact of cryptoassets on 'regulatory space' should also be thought of as a potential foning of the central banks' control over that specific monetary subspace. Specifically, there is the question of the extent to which these instruments can be forced to be part of the Perrouxian "homogenous aggregate" by being pulled on this side of the regulatory perimeter-one of the most important challenges is to raise the bar of financial literacy such as to protect consumers. In the case of cryptoassets, this is particularly important because, on the one hand, these products are more often than not operating outside of the regulatory safety zone, and, on the other hand, because many of those products come associated with a new business models that have yet to demonstrate their viability at scale.

For all the laudable democratizing impetus that lies at the origin of many a new community-based digital token (e.g., Langley and Leyshon, 2017), it is not clear how these crypto efforts represent an improvement in local economic empowerment over their physical analogues, such as, for example, the Bristol pound, the Chiemgauer, or other forms of community-issued scrip. As financial regulators continue to tighten the leash on new DTL-based FinTech products, the cost of regulatory compliance will simply be too high for many of the crypto players to survive in the medium run. There is a good historical reason why banking and finance are among the most regulated industries (because they are risky and volatile) and why, in all advanced economies, the issuance of money is a state monopoly under the control of the central bank. Even in the United States. The 'Free Banking' experiment of the mid-1800s, where private banks were engaging in competitive currency issuance, eventually ended and the Federal Reserve was created in 1913 to become the only issuer of currency.This time will be no different.

In the realm of 'currency space', the impact of the digitization of money can readily be subsumed under the heading of the competitive field of forces that is spanned by 'currency internationalization' and 'currency substitution', as discussed above. In this new frontier in the realm of monetary space, the arrival of private token-based cryptocurrencies has opened up the century-old state monopoly on currency issuance to technology-enabled private sector challengers, thus leading to a potential further weakening of central bank governance in this realm. 
In sum, we have seen that central banks have been at the very center of discussions and debates about the governance implications of digital moneyabove all, shielding their hierarchical power from blockchain-fueled disruptors. Table 22.3 summarizes the previous discussion of how to conceptualize the impact of the digitization of money on our three monetary subspaces. In particular, we can see that, in response to the digitization challenge of their control over monetary space, central banks are evaluating how to maintain, and even increase, their authority via the introduction of new digital central bank instruments. This could include such tools as general purpose central bank accounts to pin down policy space and CBDC, both in general purpose and wholesale form, to pin down control in currency space.

Somewhat paradoxically, then, in their quest to assert institutional control over digital monetary space, central banks have even been accelerating the race of digitizing currencies, pushing the boundaries further still by incubating small proofs of concepts for the use of blockchain-powered CBDC (cf. Cœré, 2018; CPMI, 2018; FSB, 2018).

\section{Outlook}

In addition to the financial fallout, the GFC also generated sizable dislocations of an intellectual nature, challenging the very core of economic orthodoxy about the self-correcting nature of markets, in general, and the efficiency of financial markets, in particular. As a result, the GFC has underlined the crucial role of central banks as institutional pivot points on which the global financial system hinges. Bolstered by their policy successes of mastering monetary stability via interest rate targeting, central bankers fully took on the mantle of policy high priests after the crisis, justifying with ease their very unorthodox policy interventions in the decade since the GFC. In any case, the crisis has impressively demonstrated that money and credit are certainly not neutral in the short and medium terms. On the one hand, the extraordinary intervention measures by central banks have created an action environment under historically unique interest conditions, whereby many of the monetary debates over the nature of the quantity theory that were long-believed to have been overcome have once more been brought to the fore. Above all, the QE policies of the C5 central banks have not only reinvented the central bank balance sheet as an instrument of monetary policy, but have also revitalized the dogmatic discussion over the nature of Quantity Theory (i.e., the relationship between money supply and prices) in its own right (e.g., Marcuzzo, 2017).

Against this background, this chapter examines the evolving role and function of central banks in the post-crisis geography of money. In particular, I turn to the pioneering work of François Perroux (1950a, b) on the analysis of economic spaces in order to argue that central banks form the institutional, operational, and functional apex in the inherent hierarchy of global monetary spaces. As such, central banks critically shape three fundamental relationships 


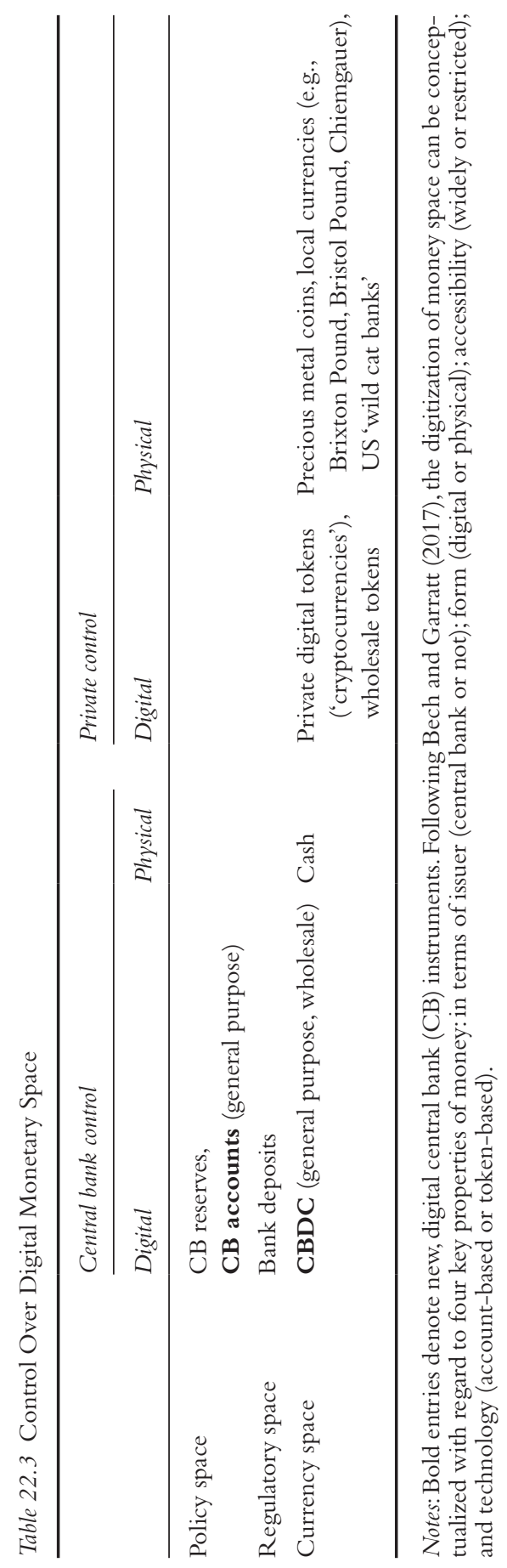

$\theta$

(†) 
among constituent economic elements in the Perrouxian system. First, they exert strong control over what I call 'policy space' - that is, the part of monetary space wherein the central banks influence economic 'plans between units' by regulating the intertemporal price of money; in other words, interest rates. Second, central banks are active in 'regulatory space', which forms a related, but distinctly separate, monetary subspace wherein central banks' regulatory and supervisory activities can be thought of as regulating the economic relations of an aggregate 'relative to the units and to their structure'. Third, I define 'currency space' as the Perrouxian monetary subspace that is spanned by competing national currencies in a constantly evolving 'field of forces' wherein national currencies vie for global dominance.

One of the implications of this chapter is to call for a deeper engagement in the rapidly evolving literature on the 'economic geography of money and finance', with the topic of central banks, on the one hand, and-perhaps more importantly-with Perroux's conceptualization of monetary space, on the other hand. Indeed, the true scope of central banks' monetary power can only be rendered fully legible in abstract economic space. Therein lies an additional motivation for a re-engagement with the novel spatial thought of François Perroux. Instead of being shackled by a singularly faithful focus on locational and agglomerational aspects that operate within the limiting confines of "banal economic space", the future potential of financial geography would be wellserved were it to be infused with a healthy dose of abstract economic spaces that de-localize economic units and economic relations.

\section{Acknowledgement}

I am grateful to the editors, Janelle Knox-Hayes and Dariusz Wójcik, for detailed comments and guidance on earlier drafts, and to participants at the 2019 AAG Meetings for helpful discussions. The usual disclaimers apply. Ben Coleman provided diligent research assistance.

\section{Notes}

1 See BIS (2019a) and CGFS (2019), for recent supranational attempts to diffuse legitimacy issues from the use of 'unconventional monetary policy tools' and their possible adverse consequences on market functioning.

2 The world's four largest financial institutions are all Chinese state-owned banks (ICBC, China Construction Bank, Agricultural Bank of China, Bank of China) with combined assets of approximately US $\$ 14$ trillion. The 10 largest privately owned financial institutions are Mitsubishi UFJ Financial (Japan), JPMorgan Chase (United States), HSBC Holdings (United Kingdom), Bank of America (United States), BNP Paribas (France), Citigroup (United States), Wells Fargo (United States), Sumitomo Mitsui Financial (Japan), Santander (Spain), and Allianz (Germany).

3 This figure includes Amazon, Disney, Facebook, Google, and Microsoft (US\$0.9 trillion); Apple, IBM, Intel, Samsung, and Sony (US\$1.1 trillion); BP, Chevron, ExxonMobile, Royal Dutch Shell, and Total (US\$1.5 trillion); BMW, Daimler, 


\section{David S. Bieri}

General Motors, Toyota and VW (US\$1.8 trillion); Anheuser-Busch, Johnson \& Johnson, Nestlé, Novartis, and Walmart (US\$0.9 trillion).

4 Goodhart and Lastra (2018) examine the challenges to central bank independence in the light of the rise of populism. Draghi (2018), Economist (2018), and Fels (2016) provide additional discussions over the renewed conflict between central bank independence and more activist monetary policy.

5 See Bieri (2017), for a detailed discussion of the role of spatial flow-of-funds analysis in economic geography.

6 August Lösch's $(1944,1949)$ pioneering analysis of the hierarchy of international monetary-financial arrangements recognizes that money and credit are always and everywhere fundamentally hierarchical in nature, and that all money is credit money, even state money. See Bieri (2019b), for more detail on Lösch's monetary theory.

7 Securities appear as both assets and liabilities of the private sector because they are both IOUs issued by some firms (liability) that are used as investments (assets) by others. See Caruana (2012), for a detailed line item explanation of central banks' balance sheets.

8 In a strict accounting sense,TARGET2 is the ECB (cf. Lubik and Rhodes, 2012).

9 In the wake of the European sovereign debt crisis, large positive and negative TARGET2 balances have arisen, causing widespread concern over the stability of the Eurozone. Much like in our example, current TARGET2 balances show the Bundesbank as a large net creditor to the ECB, and central banks in the periphery nations (Portugal, Ireland, Italy, Greece, and Spain) as significant net debtors to the ECB. See Auer and Bogdanova (2017) and Bindseil and König (2012), for more details on the TARGET2 discussion.

10 Despite some similarities between August Lösch's (1944) notion of economic space

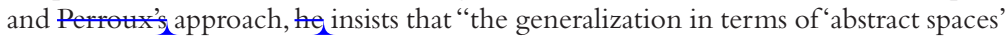
is alien to [Lösch's] important contribution" (Perroux, 1950b: 94).

11 Cf. Bieri (2009), for more details on the geographies of regulation, and Bieri (2017), for more details on the nature of regulatory space.

12 See also He and McCauley (2012) and Avdjiev et al. (2016), for details on the process of currency internationalization, and Wójcik et al. (2018), for the role of international financial centers therein.

13 Conventionally, currency internationalization is viewed as the gradual process whereby market participants (residents and non-residents alike) begin to rely on a currency outside their home country denominating bank deposits, loans, and bonds, as well as invoicing trade and making exchanges against other currencies. In the case of the Chinese renminbi, this was not a slow historic process but, rather, one that was politically orchestrated (McCauley, 2011).

14 See Davidson et al. (2008) for a general discussion of blockchains as institutional innovation, and Bieri and Datz (2019), for a more detailed discussion of the 'disruptive potential' of FinTech to the monetary-financial system.

\section{References}

Ahamed, L. (2009): Lords of Finance:The Bankers Who Broke the World. New York: Penguin Books.

Auer, R. A. and Bogdanova, B. (2017): "What Is Driving the Renewed Increase of TARGET2 Balances?," BIS Quarterly Review, 22(1): 7-9.

Avdjiev, S., McCauley, R. N., and Shin, H. S. (2016): "Breaking Free of the Triple Coincidence in International Finance," Economic Policy, 31(87): 409-451.

Bartorini, C. and Holden, H. (2019): "Proceeding with Caution: A Survey on Central Bank Digital Currency," BIS Papers No. 101. Bank for International Settlements, Basel, Switzerland. 
Bech, M. and Garratt, R. (2017): "Central Bank Cryptocurrencies," BIS Quarterly Review, 22(3): 55-70.

Bell, S. (2001): "The Role of the State and the Hierarchy of Money," Cambridge Journal of Economics, 25(2): 149-163.

Bernes, T. A., Jenkins, P., Mehrling, P., and Neilson, D. H. (2014):"China's Engagement with an Evolving International Monetary System: A Payments Perspective." Waterloo, ON, and New York City: Centre for International Governance Innovation and the Institute for New Economic Thinking.

Bieri, D. S. (2000): "Does a Central Bank's Balance Sheet Really Matter?" Unpublished mimeograph, Basel, Switzerland.

Bieri, D. S. (2009): "Financial Stability, the Basel Process and the New Geography of Regulation," Cambridge Journal of Regions, Economy and Society, 2(2): 303-331.

Bieri, D. S. (2017): "Regulatory Space and the Flow of Funds across the Hierarchy of Money," in R. L. Martin and J. Pollard (Eds.), Handbook of the Geographies of Money and Finance, Research Handbooks in Geography Series, Chap. 16, pp. 373-414. Cheltenham, UK: Edward Elgar.

Bieri, D. S. (2018): "Conceptualizing Financial Resilience: The Challenge for Urban Theory," in J. Bohland, J. Harald, and D. Brosnan (Eds.), The Disaster Resiliency Challenge: Transforming Theory to Action, pp. 89-111. Springfield, IL: Charles Thomas Publishers.

Bieri, D. S. (2019a): "After the Great Half-Century: Post-Crisis Economic Geography in Retrospect and Prospect," Working Paper. School of Public \& International Affairs, Virginia Tech, Blacksburg,VA.

Bieri, D. S. (2019b): "Hamlet without the Prince? August Lösch and How Spatial Economics Abandoned Monetary Analysis," Working Paper. School of Public \& International Affairs,Virginia Tech, Blacksburg,VA.

Bieri, D. S. and Datz, G. (2019): "Reaping the Digital Dividend: Disruption and Resilience in the Global Financial Sector,"Working Paper. School of Public \& International Affairs, Virginia Tech, Blacksburg,VA.

Bindseil, U. and König, P. H. (2012): "TARGET2 and the European Sovereign Debt Crisis," Kredit und Kapital, 45(2): 135-174.

BIS. (2019a): "Large Central Bank Balance Sheets and Market Functioning," Markets Committee Papers No. 11. Markets Committee, Bank for International Settlements, Basel, Switzerland.

BIS. (2019b): "Triennial Central Bank Survey: Foreign Exchange Turnover in April 2019." Bank for International Settlements, Basel, Switzerland.

BIS. (2020): "Central Banks and Payments in the Digital Era." BIS Annual Economic Report, pp. 67-95. Bank for International Settlements, Basel, Switzerland.

Carstens, A. (2018, December 4): "Big Tech in Finance and New Challenges for Public Policy," Keynote Address delivered at the FT Banking Summit, London.

Carstens, A. (2019a, March 23): "The Future of Money and Payments," 2019 Whitaker Lecture, Central Bank of Ireland.

Carstens, A. (2019b, March 14): “The New Role of Central Banks," in Financial Stability Institute's 20th Anniversary Conference, Basel, Switzerland.

Caruana, J. (2012): "Why Central Bank Balance Sheets Matter," in Are Central Bank Balance Sheets in Asia Too Large?, BIS Paper No. 66. Bank for International Settlements, Basel, Switzerland.

CGFS. (2019): "Unconventional Monetary Policy Tools: A Cross-country Analysis," CGFS Papers No. 63. Committee on the Global Financial System, Bank for International Settlements, Basel, Switzerland.

Clark, G. L. (2015): "The Geography of the European Central Bank: Form, Functions and Legitimacy," Journal of Economic Geography, 15(5): 855-881. 


\section{David S. Bieri}

Cœré, B. (2018): “The Future of Central Bank Money,” Speech at the International Center for Monetary and Banking Studies, European Central Bank, Frankfurt.

Cohen, B. J. (1998): "Currency Competition and Hierarchy," in B. J. Cohen (Ed.), The Geography of Money, 1st edition, pp. 92-118. Ithaca, NY: Cornell University Press.

Cohen, B. J. (2007): “The New Geography of Money," in B. J. Cohen (Ed.), Global Monetary Governance, pp. 207-224. London: Routledge.

Cohen, B. J. and Benney, T. M. (2014): "What Does the International Currency System Really Look Like?," Review of International Political Economy, 21(5): 1017-1041.

CPMI. (2018): "Central Bank Digital Currencies," CPMI Papers No. 174. Committee on Payments and Market Infrastructures, Markets Committee, Bank for International Settlements, Basel, Switzerland.

Crowe, C. and Meade, E. E. (2008):“Central Bank Independence and Transparency: Evolution and Effectiveness," IMF Working Paper No. 08/116. International Monetary Fund, Washington, DC.

Davidson, S., di Filippi, P., and Potts, J. (2018): "Blockchains and the Economic Institutions of Capitalism," Journal of Institutional Economics, 14(1): 639-658.

Draghi, M. (2018): “Central Bank Independence," First Lamfalussy Lecture at the National Bank of Belgium, Brussels.

Dwyer, G. P. (2015): “The Economics of Bitcoin and Similar Private Digital Currencies," Journal of Financial Stability, 17(1): 81-91.

Economist. (2018, October 20): "A Debate about Central-bank Independence Is Overdue," Finance and Economics Section.

Eichengreen, B., Mehl,A., and Chitu, L. (2017): How Global Currencies Work: Past, Present, and Future. Princeton, NJ: Princeton University Press.

El-Erian, M. (2016): The Only Game in Town: Central Banks, Instability, and Avoiding the Next Collapse. New York: Random House.

Fels, J. (2016, May): “The Downside of Central Bank Independence," PIMCO Macro Perspectives.

French, S., Leyshon, A., and Wainwright, T. (2011). "Financializing Space, Spacing Financialization," Progress in Human Geography, 35(6): 798-819.

FSB. (2018): "Crypto-Assets," Report to the G20 on Work by the FSB and StandardSetting Bodies, Financial Stability Board, Basel, Switzerland.

Garriga, A. C. (2016): "Central Bank Independence in the World: A New Data Set," International Interactions, 42(5): 849-868.

Goodhart, C. A. E. and Lastra, R. (2018): "Populism and Central Bank Independence," Open Economies Review, 29(1): 49-68.

Gurley, J. G. and Shaw, E. S. (1960): Money in a Theory of Finance. Washington, DC: Brookings Institution Press.

He, D. and McCauley, R. N. (2012): "Eurodollar Banking and Currency Internationalization," BIS Quarterly Review, 17(3): 33-46.

Helleiner, E. (1994): States and the Reemergence of Global Finance: From Bretton Woods to the 1990s , Ithaca, NY, and London: Cornell University Press.

Helleiner, E. (2010): "A Bretton Woods Moment? The 2007-2008 Crisis and the Future of Global Finance," International Affairs, 86(3): 619-636.

Kirshner, J. (2014): "Same as It Ever Was? Continuity and Change in the International Monetary System," Review of International Political Economy, 21(5): 1006-1017.

Langley, P. and Leyshon, A. (2017): "Platform Capitalism: The Intermediation and Capitalization of Digital Economic Circulation," Finance and Society, 3(1): 11-31.

Leyshon, A. and Thrift, N. (1997): Money/Space: Geographies of Monetary Transformation, London/New York: Routledge.

Lösch, A. (1944): Die räumliche Ordnung der Wirtschaft, 2nd edition. Jena: G. Fischer. 
Lösch, A. (1949): “Theorie der Währung: Ein Fragment,” Weltwirtschaftliches Archiv, 62: $35-88$

Lubik, T. A. and Rhodes, K. (2012): "TARGET2: Symptom, Not Cause, of Eurozone Woes," Federal Reserve Bank of Richmond Economic Brief, 5(8): 1-5.

McCauley, R. N. (2011): "Internationalizing the Renminbi and China's Financial Development Model," Council on Foreign Relations Working Paper, Washington, DC.

Mann, G. (2010): “Hobbes' Redoubt? Toward a Geography of Monetary Policy," Progress in Human Geography, 34(5): 601-625.

Mann, G. (2012): "Release the Hounds! The Marvelous Case of Political Economy," in T. J. Barnes, J. A. Peck, and E. Sheppard (Eds.), The Wiley-Blackwell Companion to Economic Geography, pp. 61-73. Chichester, UK: John Wiley \& Sons, Inc.

Marcuzzo, M. C. (2017): “The 'Cambridge' Critique of the Quantity Theory of Money: A Note on How Quantitative Easing Vindicates It," Journal of Post Keynesian Economics, 40(2): 260-271.

Martin, R. L. (1999): Money and the Space Economy. Chichester: John Wiley \& Sons.

Mehrling, P. G. (2011): The New Lombard Street: How the Fed Became the Dealer of Last Resort. Princeton, NJ: Princeton University Press.

Mehrling, P. G. (2013): "The Inherent Hierarchy of Money," in Social Fairness and Economics: Economic Essays in the Spirit of Duncan Foley Festschrift, Routledge Frontier of Political Economy, pp. 394-404. New York: Routledge.

Mehrling, P. G. (2015): "Elasticity and Discipline in the Global Swap Network," International Journal of Political Economy, 44(4): 311-324.

Minsky, H. P. (1977): "The Financial Instability Hypothesis: An Interpretation of Keynes and an Alternative to 'Standard'Theory," Challenge, 20(1): 20-27.

Minsky, H. P. (1993): “On the Non-Neutrality of Money," Federal Reserve Bank of New York Quarterly Review, 18(1): 77-82.

Minsky, H. P. (2008): Stabilizing an Unstable Economy. New York: McGraw Hill.

Obstfeld, M., Stambaugh, J. C., and Taylor,A. M. (2010):"Financial Stability, the Trilemma, and International Reserves," American Economic Journal: Macroeconomics, 2(1): 57-94.

Perroux, F. (1950a): "The Domination Effect and Modern Economic Theory," Social Research, 17(2): 188-206.

Perroux, F. (1950b): "Economic Space: Theory and Application," Quarterly Journal of Economics, 64(1): 89-104.

Raskin, M. and Yermack, D. (2017): "Digital Currencies, Decentralized Ledgers, and the Future of Central Banking," in P. Conti-Brown and R. Lastra (Eds.), Research Handbook on Central Banking, pp. 474-486. Cheltenham, UK: Edgar Elgar.

Schilling, L. and Uhlig, H. (2019):"Some Simple Bitcoin Economics," Journal of Monetary Economics, 107: 16-26.

Subacchi, P. (2010): "Who Is in Control of the International Monetary System?," International Affairs, 86(3): 665-680.

Terzi, A. (2005): "International Financial Instability in a World of Currencies Hierarchy," Working Papers of the Istituto di Economia e Finanza, Università Cattolica del Sacro Cuore, Dipartimenti e Istituti di Scienze Economiche (DISCE), Milan, Italy.

Thrift, N. and Olds, K. (1996): "Refiguring the Economic in Economic Geography," Progress in Human Geography, 20(3): 311-337.

Tucker, P. (2018): Unelected Power: The Quest for Legitimacy in Central Banking and the Regulatory State. Princeton, NJ: Princeton University Press.

Wójcik, D., Knight, E., and Pažitka, V. (2018): "What Turns Cities into International Financial Centres? Analysis of Cross-border Investment Banking 2000-2014," Journal of Economic Geography, 18(1): 1-33. 